\title{
SERI FANTASTEEN GHOST DORMITORY: PRODUKSI KOMERSIAL SASTRA DI INDONESIA
}

\author{
Alberta Natasia Adji \\ Kajian Sastra dan Budaya, Universitas Airlangga \\ E-mail: adji.alberta@yahoo.com
}

\begin{abstract}
Abstrak
Tren genre horor kini telah merambah dunia sastra Indonesia yang ditandai dengan munculnya light novel karya remaja berusia 13-18 tahun di bawah label Fantasteen yang diterbitkan oleh DAR! Mizan mulai tahun 2011, salah satu divisi dari PT Mizan Pustaka, kelompok penerbit terbesar di Indonesia. Di antara sekian banyak light novel Fantasteen yang telah beredar, serial Ghost Dormitory menjadi yang paling menonjol karena setiap cerita dikhususkan pada satu kota asing yang spesifik seperti Tanzania, Den Haag, dan sebagainya. Artikel ini bertujuan untuk mengungkap fenomena keterkaitan antara karya sastra dengan perspektif komersial melalui kritik arena produksi kultural yang diajukan Pierre Bourdieu dan teori Fantastic Tzvetan Todorov. Menggunakan metode kualitatif, artikel ini mencermati bahwa DAR! Mizan berhasil memperoleh legitimasi populer berkat kelahiran sejumlah light novel bertema horor yang dikemas lewat lini Fantasteen yang ditulis oleh remaja dan ditargetkan pula untuk pembaca muda. Dengan munculnya sebuah serial khusus Ghost Dormitory di antara karya-karya Fantasteen lain, hasil penelitian ini menunjukkan bahwa sebagai salah satu penerbit mayor, DAR! Mizan telah meluncurkan strategi yang mempengaruhi wajah dunia sastra remaja Indonesia yang tengah menghadirkan genre horor sebagai tema utamanya.
\end{abstract}

Kata Kunci: Ghost Dormitory, fantasi, perspektif komersial, arena produksi kultural

\begin{abstract}
The trend of horror genre has spread towards Indonesian literature, marked by the emergence of light noves for teenagers aged 13-18 under the label of Fantasteen, an imprint of DAR! Mizan starting in 2011, a division of PT Mizan Pustaka, one of the biggest publishing companies in Indonesia. Among various printed Fantasteen light novels, the Ghost Dormitory series became the most prominent work as each story is set in
\end{abstract}


one foreign city such as Tanzania, Den Haag, etc. The study reveals the interconnecting phenomenon between literary works and commercial ways through the perspective of Pierre Bourdieu's the field of cultural production and Tzvetan Todorov's Fantastic theory. Using a qualitative method, this article proves that DAR! Mizan has successfully achieved popular legitimation owing to the rising horror-themed light novels which are presented through Fantasteen brand, written by teenagers and also targeted for young readers. With the rise of the special series Ghost Dormitory among other Fantasteen works, the result of the study shows that as one of the major publishers, DAR! Mizan has successfully conducted a strategy to influnce the face of the Indonesian teenage literary world which is presenting a horror genre as its main theme.

Keywords: Ghost Dormitory, fantasy, commercial perspective, the field of cultural production

\section{PENDAHULUAN}

Sejak tahun 1992, dunia sastra anak dan remaja di Indonesia diramaikan oleh kemunculan lini DAR! Mizan (Divisi Anak dan Remaja) sebagai divisi Penerbit Mizan yang secara khusus menerbitkan seri-seri buku anak dan remaja seperti KKPK (Kecil-Kecil Punya Karya), PBC (Pink Berry Club), dan Fantasteen*. Di antara ketiganya, Fantasteen yang didirikan pada 2011 menempati posisi yang cukup spesial lantaran dilahirkan dari tangan-tangan para penulis yang masih berusia remaja dan dengan spesifikasi genre kisah-kisah menantang seperti fantasi atau horor tanpa unsur romance di dalamnya. Karya-karya Fantasteen yang telah terbit mayoritas mengusung genre horor sebagai tema utamanya, dan yang paling menonjol ialah serial Ghost Dormitory yang masing-masing versinya mengambil latar tempat di salah satu kota asing yang berada di

\footnotetext{
*Sumber: http://www.mizan.com/dar/. KKPK diperuntukkan penulis berusia 4-12 tahun, PBC 1316 tahun, dan Fantasteen 13-18 tahun.
} 
luar Tanah Air. Ada lebih dari sepuluh kota asing di dunia yang digunakan sebagai setting cerita, antara lain Hiroshima, Tokyo, Seoul, Paris, Vienna, Hamburg, Madrid, Den Haag, Kairo, New York, Sidney, Alaska, dan Tanzania. Di antara belasan kisah tersebut, dua cerita yang berjudul Ghost Dormitory in Tanzania (2016) karya Mahesi Moktikanana dan Ghost Dormitory in Den Haag (2015) karya Melsah Elmania cukup unik lantaran walau termasuk dalam kategori light novel horor yang judulnya mengandung unsur keberadaan ghost atau hantu/makhluk halus/astral, keduanya nyaris tidak menggunakan hantu sebagai tema utamanya, melainkan unsur tenung atau teluh dari suku-suku primitif di Tanzania yang ditujukan pada seorang gadis albino dan gangguan psikologis yang destruktif, yang diderita oleh seorang gadis SMP di Den Haag.

Genre horor sendiri telah menjadi genre yang sejak dulu telah merebak luas tidak hanya pada film-film atau buku-buku dewasa namun juga tontonan dan bacaan anak-anak. Yang menarik, orang seolah tak pernah jenuh menghadirkan makhluk-makhluk supernatural tersebut ke kisah-kisah yang terlahir di era modern, yang menunjukkan bahwa,

"[Our]...interest in fearsome fantasies cannot be completely explained as the result of a desire to understand the unknown. Still, the legends of the past provided many of the monsters that haunt the literature of the present, and part of the modern enthusiasm for the macabre may be attributed to ancestral memories of the days when demons were almost expected to put in an occasional experience." (Daniels, L., 1977:8)

Lewat pernyataan tersebut, ditegaskanlah fakta bahwa orang pada umumnya memiliki kecenderungan merindukan masa lalu di mana kehidupan masih begitu dekat dengan hal-hal mistik serta berhubungan 
dengan roh halus, monster, makhluk asing dan dunia lain. Oleh karena kesulitan untuk mengalami sendiri atau menyaksikan hal-hal tersebut di dunia kontemporer yang sangat maju, maka lewat kisah-kisah yang menjadi produksi kultural-lah hal tersebut diceritakan kembali.

Smith dan Rosenthal (2005, dalam Gilmore dan Campbell, 2008:4) berkata bahwa anak-anak dan remaja cenderung menikmati kisah-kisah berbau misteri, horor ataupun supernatural karena mereka merasa puas sekaligus percaya diri jika berhasil mengalahkan rasa takut dan kecemasan setelah membayangkan diri berada dalam situasi-situasi menegangkan semacam itu. Genre horor atau misteri sering menjadi semacam tantangan bagi kaum muda untuk ajang uji nyali dan tolak ukur keberanian seseorang dalam menghadapi ketakutan-ketakutannya dalam hidup. Alasan lain kaum muda menyukai genre-genre tersebut ialah mereka dapat sejenak mengalihkan pikiran dari kebosanan rutinitas kehidupan sehari-hari.

Hal ini lantas berujung pada meningkatnya popularitas genre horor pada bacaan anak-anak dan remaja. Menariknya, anak-anak yang sering dianggap lugu dan polos justru lebih mudah tertarik melakukan hal-hal berbahaya ketimbang orang dewasa, dan karenanya banyak dari kisahkisah horor justru menggunakan anak-anak sebagai karakter hantu atau setan daripada sebagai karakter korban yang tak berdaya (Erikkson, 2013). Boleh jadi anak-anak sangat menipu dengan penampilan mereka yang lebih sering mengundang simpati dari orang dewasa, namun di film-film horor mereka-lah yang justru lebih kejam sebagai setan atau hantu. Barangkali itulah mengapa para penulis naskah film, video, maupun novel lebih suka menggunakan anak-anak sebagai tokoh hantu atau setidaknya 
pasti menghadirkan tokoh anak-anak dalam cerita-cerita misteri yang mereka buat. Hal itu rupanya juga memengaruhi penulis-penulis muda.

Sharon dan Woolley (2004) dalam penelitian mereka terhadap anakanak balita, mengungkapkan bahwa walau pada usia yang bisa dibilang masih sangat belia, anak-anak di usia muda telah belajar untuk menempatkan kepercayaan mereka terhadap hal-hal yang berbau fantasi seperti monster, sinterklas, peri, dan sebagainya dalam kategori ketiga, yakni di tengah-tengah keberadaan suatu hal yang pasti ada dan hal yang keberadaannya dipertanyakan. Jelaslah bahwa kebanyakan anak-anak tak begitu saja membuang atau malah kebingungan menentukan apakah tokoh sinterklas atau monster dari cerita legenda itu ada atau tidak, tapi mereka tetap menyimpannya dalam alam bawah sadar dan pikiran, yang selanjutnya pemahaman mereka tersebut akan berkembang seiring waktu. Akhirnya, mereka dapat terus merekonstruksi pemahaman tersebut tanpa benar-benar menghilangkannya lewat karya-karya bergenre fantasi, misteri atau horor.

Senada dengan fenomena kemunculan karya-karya penulis muda dari lini Fantasteen, Jeannie Banks Thomas (2007) lewat artikelnya yang berjudul The Usefulness of Ghost Stories dalam buku Haunting Experiences: Ghosts in Contemporary Folklore menjelaskan bahwa kisah-kisah hantu biasanya sangat kental diwarnai dengan nilai-nilai tradisi dan budaya setempat yang mendasarinya. Tentunya setiap negara, kota, dan daerah memiliki kisah dan ke-khas-annya yang berbeda-beda. Fakta tersebut cukup mendukung terciptanya serial Ghost Dormitory yang mengambil latar tempat di sejumlah kota asing di luar negeri, yang juga mampu menarik pembaca untuk melihat seperti apa budaya kisah hantu di negara lain. 
Dipilihnya dua light novel dari serial Ghost Dormitory yang diterbitkan oleh Fantasteen, yakni Ghost Dormitory in Den Haag dan Ghost Dormitory in Tanzania didasarkan pada aspek-aspek berikut, yaitu: (1) Serial Ghost Dormitory berbeda dari light novel Fantasteen yang lain karena ber-setting di sejumlah kota asing di luar Indonesia; (2) sebagai novel bergenre horor atau hantu, kedua novel tersebut menawarkan perspektif yang berbeda dari mayoritas novel-novel bergenre serupa; dan (3) keberadaan novelnovel tersebut merepresentasikan fenomena sastra dalam perspektif komersial yang melahirkan praktik sistem produksi kultural yang sedang marak terjadi di masyarakat Indonesia saat ini.

Pemikiran Tzvetan Todorov bahwa fantasi atau le fantastique mampu menjadi sebuah genre diawali dari pendapatnya bahwa manusia bisa mengambil dua opsi dalam mempersepsi kejadian-kejadian tertentu dalam kehidupan yang tak bisa dirasionalisasi, yakni mereka bisa melupakan dan menganggap semuanya sebagai mimpi di siang bolong belaka, atau menerimanya dan percaya bahwa ada aturan-aturan yang selama ini belum bisa dipahami manusia (Santana, 2006). la menyebutkan tiga kriteria bagi sebuah karya untuk dapat dikategorikan sebagai genre fantasi: (1) pembaca membayangkan tokoh-tokoh dalam kisah-kisah tersebut hidup sebagai manusia sungguhan dan bimbang menentukan penjelasan mengenai peristiwa-peristiwa tak lazim yang dihadapinya; (2) kebutuhan akan dilema yang dirasakan oleh tokoh tersebut; (3) pembaca mampu menginterpretasi sendiri makna dari kisah-kisah tersebut.

Dalam genre fantasi, pembaca atau audiens menjadi elemen yang krusial karena merekalah yang pada akhirnya menentukan bagaimana genre tersebut diselami. Pembaca boleh memutuskan bahwa aspek-aspek 
riil dari realita tetap yang paling bisa dipercaya atau malah bertindak sebaliknya, yaitu menerima anomali-anomali alam begitu saja tanpa penjelasan ilmiah. Todorov (1975, dalam Santana, 2006:189) lantas mencetuskan dua genre mayor murni, yakni "the uncanny" atau bisa diartikan sebagai 'yang aneh atau gaib' dan "the marvelous" atau yang didefinisikan sebagai 'yang luar biasa'.

"At the story's end, the reader makes a decision even if the character does not; he opts for one solution or the other, and thereby emerges from the fantastic. If he decides that the laws of reality remain intact and permit an explanation of the phenomena described, we say that the work belongs to another genre: the uncanny. If, on the contrary, he decides that new laws of nature must be entertained to account for the phenomena, we enter the genre of the marvelous." (Todorov, 1975:41)

Jika pembaca percaya pada penjelasan logis dari fenomena misterius yang disuguhkan dalam kisah-kisah tersebut, maka genrenya ialah uncanny, sementara bila pembaca langsung saja menerima hal-hal gaib di dalamnya, maka suatu karya termasuk dalam genre marvelous. Yang jelas, Santana (2006:189) mengklaim bahwa cerita-cerita horor yang mengandung unsur ketakutan dan teror untuk pembaca termasuk dalam genre uncanny, oleh karena sederet peristiwa gaib yang ada sepanjang plot dapat terungkap dengan penjelasan yang logis di bagian akhir cerita.

Suatu produksi karya sastra pada hakikatnya memang takkan mungkin terlepas dari kondisi lingkungan sosio-kultural masyarakat di sekitarnya. Pierre Bourdieu dalam basis pemikirannya mengenai fenomena produksi sastra menyatakan bahwa,

"The science of the literary field is a form of analysis situs which establishes that each position-e.g. the one which corresponds to a 
genre such as the novel, or within this, to a sub-category to a genre such as the novel or, within this, to a sub-category such as the 'society novel' [roman mondain] or 'the popular novel'-is subjectively defined by the system of distinctive properties by which it can be situated relative to other positions..." (The Field of Cultural Production, 1993:30)

Pernyataan tersebut menegaskan jika keberadaan setiap karya sastra seperti novel yang memiliki bermacam-macam sub-genre yang spesifik sekaligus yang beredar bebas dalam masyarakat sesungguhnya diatur lewat tangan-tangan kapitalis yang dominan terhadap sistem distribusi produksi kultural itu sendiri. Karenanya, kemunculan novel-novel bergenre asmara, metropolitan, misteri, horor dan sebagainya sesungguhnya bukan ditentukan oleh masyarakat namun para penerbit yang memiliki akses dan kuasa terhadap alur percetakan, penerbitan serta pendistribusian secara luas pada khalayak. Karnanta (2013:4) menjelaskan bahwa interaksi dalam tatanan ruang sosial dapat terjadi karena adanya agen-agen yang memiliki peran serta ciri yang berbeda-beda namun sesungguhnya terhubung antara satu dengan lainnya. Dengan kata lain, sebuah status ataupun posisi sosial diperoleh agen-agen tersebut melalui kedudukan/wewenang serta habitus mereka untuk menciptakan sebuah praktik yang menentukan standar kelayakan sebuah produk dan bagaimana produk tersebut diasosiasikan dengan kategori atau golongan tertentu dalam masyarakat.

Lewat Social Space and Symbolic Power, Pierre Bourdieu (1989:19) menjelaskan bahwa "Habitus is both a system of schemes of production of practices and a system of perception and appreciation of practices", yang mana dimaknai secara singkat dan padat bahwa habitus tidak lain dan tidak bukan ialah selera. Konsep Bourdieu tersebut mengungkapkan 
kenyataan bahwa selera seseorang sesungguhnya dibentuk dengan sengaja melalui tangan-tangan kaum dominan kapitalis yang mempunyai kuasa dalam menentukan atau menyetir tren mayoritas. Berlawanan dengan asumsi kaum awam selama ini yang menganggap selera merujuk pada pilihan atau ketertarikan bebas yang murni dari seseorang, maka selera merupakan hasil dari strategi-strategi klasifikasi, pengkondisian sosial, dan standar-standar yang ditetapkan lebih dulu oleh kaum-kaum yang berkuasa. Dalam hal ini, Haryatmoko (2016) mendefinisikan keterkaitan habitus dan champ atau arena perjuangan sebagai hubungan timbal-balik yang saling mempengaruhi. Posisi para pelaku atau agen yang berperan di dalamnya tersusun secara hirarkis, dan terutama dibedakan oleh besar kecilnya kepemilikan modal ekonomi yang dipunyai masingmasing pihaknya.

Dengan menggunakan metode kualitatif, pengumpulan data dalam penelitian ini dilakukan dengan mengambil potongan dialog dalam kedua novel yang telah dipilih. Kata-kata dan kalimat yang menjadi bukti pendukung dari tujuan studi akan dianalisis dan diinterpretasi, lalu juga dibuat skema untuk merangkum konsep dasarnya yang berhasil diperoleh. Selanjutnya, data akan dianalisis menggunakan teori fantasi oleh Tzvetan Todorov dan teori produksi kultural oleh Pierre Bourdieu.

\section{PEMBAHASAN}

\section{Genre Horor dalam Industri Budaya dan Sastra Indonesia}

\section{Historiografi Horor di Indonesia}

Sejak dulu, Indonesia ramai dengan keberadaan film-film layar lebar bertema horor seperti Sundelbolong (1981), Kuntilanak (2006), Terowongan Casablanca (2007), Pintu Terlarang (2009) dan masih banyak 110 | ISSN: 22477-5150 http://journal.unesa.ac.id/index.php/jpi 
lainnya. Film-film horor yang selama ini telah banyak dirilis tersebut juga mayoritas terkait dengan tradisi dan budaya setempat yang percaya akan hantu-hantu kuntilanak, pocong, dan sebagainya. Mulai tahun 2000an, tren horor tersebut juga merambah ke karya sastra Indonesia, yang ditandai dengan munculnya novel-novel misteri seperti Unforgiven: Hantu Rumah Hijau (2014), 13: Kumpulan Cerpen Horor (2015), Penghuni Tanah Tabu (2015), Misteri Patung Garam (2015), Gerbang Dialog Danur (2015) dan Tewasnya Gagak Hitam (2016). Kebanyakan dari novel-novel tersebut ditujukan pada pembaca dewasa karena beratnya unsur psikologis yang disuguhkan di dalamnya. Jarang ada kisah-kisah horor yang khusus ditargetkan pada pembaca muda walaupun ada kemungkinan mereka mengonsumsi bacaan-bacaan horor dewasa.

Lini Fantasteen dari DAR! Mizan pertama kali dihadirkan pada tahun 2011 untuk menjembatani para penulis muda dari rentang usia 13-18 tahun untuk menyalurkan tulisan-tulisan mereka dalam genre fantasi. Uniknya, para penulis muda Fantasteen lebih banyak mengeksplor genre horor yang menampilkan hantu dan unsur-unsur misteri ketimbang unsurunsur fantasi yang lebih kepada sihir dan makhluk-makhluk dalam legenda atau mitos fantasi murni. Di antara judul-judul yang telah diterbitkan, serial Ghost Dormitory menjadi yang paling menarik perhatian oleh karena sejauh ini Fantasteen hanya membuat satu serial khusus di antara novelnovel lepas yang selama ini banyak mereka terbitkan. Terlebih lagi, Ghost Dormitory memang dicanangkan agar masing-masing kisahnya bisa mengambil latar tempat di sekolah asrama yang ada di sejumlah kota asing di luar Indonesia sebagai daya tarik utama bagi pembaca sekaligus untuk mengetahui kisah-kisah misteri dari negara dan budaya lain. 
Karenanya, dapat disimpulkan bahwa tren genre sastra horor di Indonesia memiliki pengaruh yang sangat kuat dari kepercayaan masyarakat setempat akan tradisi serta budaya mistik yang mendasarinya. Demikian pula, sejarah kisah bergenre horor di Indonesia telah berlangsung cukup lama dengan cara dipopulerkan lewat industri film dan yang terbaru kini melalui industri sastra yang berupa kemunculan light novel-light novel remaja bergenre serupa.

\section{Horor sebagai Uncanny}

Tzvetan Todorov menjelaskan bahwa uncanny cenderung tak jelas dan lebih sering mengundang rasa ketakutan bagi pembaca atau audiensnya, "The uncanny realizes, as we see, only one of the conditions of the fantastic: the description of certain reactions, especially of fear" (1975:47). la juga mengkategorikan kedua genre mayor tersebut menjadi dua subgenre, yakni "the fantastic-uncanny" atau 'fantasi aneh atau gaib' dan "the fantastic-marvelous" atau 'fantasi luar biasa' yang didasari oleh munculnya penjelasan logis dan rasional di bagian akhir yang menerangkan terjadinya peristiwa-peristiwa gaib yang ada di sepanjang cerita (Santana, 2006).

Novel Ghost Dormitory in Den Haag (2015) yang ditulis Melsah Elmania berpusat pada sudut pandang dua tokoh utama, yakni Vanda dan Azol, teman sekolahnya yang baru pindah dari Indonesia. Misteri dimulai dari ditemukannya sebatang anggrek jenis langka berwarna abu-abu ketika mereka tengah mengadakan penelitian Biologi di taman botani sekolah. Vanda yang menanam dan merawat anggrek tersebut di kamarnya mulai dihantui secara rutin oleh suara seorang gadis yang tampaknya berasal dari bunga tersebut. Perlahan, satu demi satu orang-orang terdekatnya ditemukan meninggal secara misterius, termasuk ayahnya sendiri. Tak 
Alberta Natasia Adji, Seri Fantasteen...(hal. 102-120)

tahan lagi bahwa anggrek tersebut adalah pembunuhnya, ia mengkonfrontasi bunga tersebut, yang rupanya menjelma menjadi sisi jahat Vanda sendiri. Setelah gadis itu berhasil mengalahkan sosok lain dirinya tersebut dengan menghancurkan pot anggrek, ia pingsan dan Azol membawanya ke psikolog untuk pertolongan lebih lanjut.

\footnotetext{
"“Skizofrenia paranoid?"

"Iya. Itulah yang menyebabkannya membunuh adik, staf sekolah, dan nyaris membunuh ayahnya sendiri."

"Apakah dia gila?"

"Kita tidak bisa menyebut dia 'sepenuhnya' gila. Dia hanya terjebak dalam kepribadiannya yang lain. Butuh terapi dan obat antipsikotik."” (Elmania, 2015:145)
}

Menyimak dari penggalan dialog antara Azol dan psikolog asrama di atas, pembaca akhirnya dapat mengetahui apa yang sebenarnya terjadi pada diri Vanda dan peristiwa-peristiwa kematian yang seolah terus mengejarnya. Setelah membaca penjelasan yang dipaparkan di bagian epilog tersebut, pembaca lantas memahami bahwa kejadian-kejadian mengerikan dan tak logis yang selama ini dialami tokoh Vanda sebenarnya merupakan hasil perbuatannya sendiri, yang diakibatkan kondisi mental yang tidak stabil. Pembaca dihadapkan pada penjelasan rasional bahwa sang tokoh utama rupanya mengalami berbagai problem rumit dalam kehidupan keluarganya sehingga akhirnya ia hanya mampu memendam amarah, yang kemudian dilampiaskannya lewat serangkaian pembunuhan yang dikendalikan oleh alam bawah sadarnya, yang kemudian hendak mengontrol kesadarannya. Jelas, hal tersebut meruntuhkan asumsi-asumsi dan ekspektasi awal pembaca bahwa anggrek tersebut memang menjadi wadah atau medium bersemayamnya makhluk halus yang mencoba 
mengganggu sang tokoh utama. Vanda sesungguhnya tak pernah bertemu hantu ataupun makhluk astral lainnya, tapi ia hanya berhadapan dengan 'kegilaan' dirinya sendiri, yang sampai akhir masih tak disadarinya.

Lain halnya untuk Ghost Dormitory in Tanzania (2016) yang ditulis Mahesi Moktikanana, tokoh utama Olivia Smith yang terlahir dengan kekurangan fisik sebagai albino harus berkali-kali menerima kutukan, tenung dan teluh yang dikirimkan suku-suku primitif Tanzania di tempat tinggal barunya. Sedari awal ia diincar sebagai tumbal bagi dukun-dukun dari tiga suku yang masih memegang teguh ajaran tradisi nenek moyang mereka yang melakukan praktik ilmu hitam untuk mendapatkan kesaktian serta memenuhi kebutuhan hidupnya, sehingga pembaca tak lagi bertanya-tanya siapa dan apa yang menyebabkan semua itu terjadi.

“"Apa? Tunggu-tunggu. Dukun?” Olivia masih tidak mengerti. Cerita yang didengarnya terkesan konyol.

"Negara ini memang terlihat aman-aman saja. Namun, sebenarnya banyak dukun sakti berasal dari Tanzania. Dukun-dukun itu percaya bahwa seorang albino dapat meningkatkan kekuatan dan kekayaan. Dengan kata lain, jika ada dukun yang mengetahui keberadaanmu di sini, maka nyawamu terincar, Miss Smith," terang Mrs Jackson."' (Moktikanana, 2016:82)

Jelaslah bahwa Olivia mengalami berbagai kejadian tak mengenakkan di asrama barunya bukan karena gangguan hantu atau roh halus melainkan oleh ulah para dukun suku-suku Kiyuku, Malawi, dan Tanzania. Kejadian-kejadian mistis nan irasional yang dialami Olivia langsung disertai dengan penjelasan yang masuk akal, yakni bahwa dirinya tengah dipermainkan suku-suku primitif menggunakan black magic. Tema-tema semacam itu sering ditemukan dalam kisah-kisah tradisi suku primitif yang masih memegang teguh ajaran nenek moyang mereka akan ilmu dukun. Di 
Indonesia, banyak orang, terutama yang tinggal di desa, masih memercayai kekuatan mistis sebagai sarana yang ampuh untuk mencapai tujuan. Digambarkan dalam skema sebagai berikut:

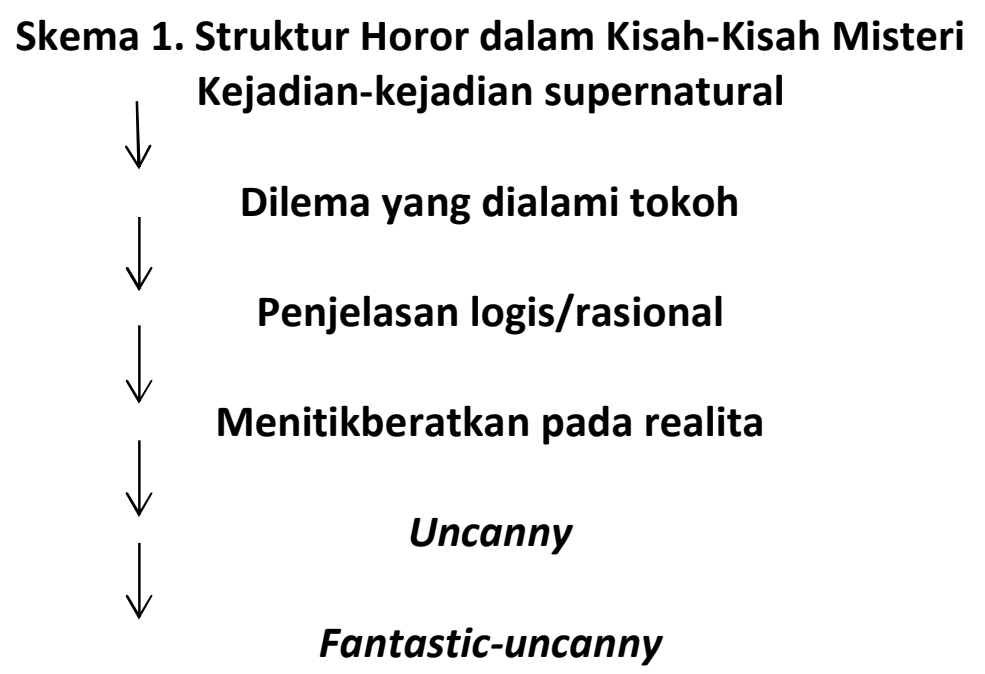

Kesimpulannya, kisah-kisah horor yang disuguhkan lewat seri Ghost Dormitory berakhir dengan penjelasan yang menitikberatkan unsur realita yang telah disalahpahami atau terdistorsi sehingga termasuk dalam genre mayor uncanny atau gaib/aneh. Dan karena horor masih termasuk dalam genre fantasi, sebagaimana Ghost Dormitory beredar di bawah lini penerbitan Fantasteen, maka seri novel tersebut dapat dimasukkan sebagai kategori sub-genre fantastic-uncanny atau fantasi gaib/aneh. Lewat pengaplikasian teori fantasi Todorov, seri Ghost Dormitory masih bisa dikategorikan sebagai genre fantasi walau sifatnya uncanny karena lebih merujuk pada penjelasan rasional yang mendasari kejadian-kejadian supernatural yang ada di dalam kisah-kisahnya.

\section{Sastra dalam Produksi Kultural}


Pierre Bourdieu (1993) menyatakan bahwa praktik perebutan posisi dalam arena produksi kultural, yang melibatkan agen-agen atau pelakupelaku yang saling terhubung dan mempengaruhi satu sama lain, sesungguhnya ialah:

"...is nothing other than the structure of distribution of the capital of specific properties which governs success in the field and the winning of the external or specific profits (such as literary prestige) which are at stake in the field." (Bourdieu, 1993:30)

Hal ini diartikan bahwa tren sastra yang beredar dalam masyarakat dan didistribusikan di toko-toko buku sesungguhnya diatur dan direncanakan oleh pihak-pihak penerbit yang berkuasa dalam menentukan genre apa yang saat ini dibutuhkan, disukai, dan tentu saja laris. Sebagaimana layaknya penulis-penulis pemula maupun penerbit-penerbit baru yang hendak meraih legitimasi dalam dunia sastra, tentunya pihakpihak tersebut akan berusaha sekuat tenaga untuk dapat secepatnya memperoleh pengakuan tersebut melalui strategi-strategi tertentu. Sebagai agen-agen budaya, maka baik penulis maupun penerbit bekerja sama dalam merumuskan suatu strategi sebagai cara untuk memantapkan posisi mereka di arena sastra Indonesia, dan salah satunya ialah menetapkan genre yang spesifik pada proses kelahiran sebuah karya.

Sebagai perusahaan besar, Mizan yang telah memiliki banyak anak perusahaan telah membagi-bagi tema dan genre berbeda yang dapat ditangani tiap-tiap divisinya. Contohnya ialah lini DAR! Mizan yang memang diperuntukkan demi mewadahi penulis-penulis cilik untuk berkarya. Mereka membaginya menjadi tiga kelompok, yakni KKPK (KecilKecil Punya Karya), PBC (Pink Berry Club) dan Fantasteen. Untuk yang 
golongan terakhir, target penulis maupun pembaca ialah remaja yang kirakira menduduki bangku SMP dan SMA. DAR! Mizan memberi persyaratan bahwa Fantasteen hanya menerima kisah-kisah fantasi tanpa adanya bumbu romansa apapun di dalamnya. Setelah cukup lama berjalan, karyakarya yang beredar di bawah bendera Fantasteen rupanya mayoritas mengambil tema horor daripada fantasi murni, yang mana dapat dihubungkan erat dengan kepercayaan kuat masyarakat Indonesia akan hantu dan dunia makhluk halus. Oleh karena banyak penulis remaja Fantasteen yang mengambil kisah-kisah horor, maka penerbit lantas menciptakan sebuah seri khusus di mana baik para penulis muda maupun pembacanya mampu menengok kisah-kisah hantu dari negeri-negeri lain, yakni melalui seri Ghost Dormitory, yang hingga kini telah terbit melampaui sepuluh jilid.

Yang menjadi tanda tanya besar terhadap fenomena tersebut ialah fakta bahwa penerbit DAR! Mizan justru mendukung dan mengakomodasi pertumbuhan genre horor dalam karya sastra yang ditargetkan bagi kaum muda atau bahkan anak-anak, yang notabene masih belum terlalu memahami persoalan dunia. Bisa jadi memang anak-anak dan remaja telah mendapat pendidikan yang cukup sehingga mereka dapat membedakan mana hal-hal khayalan dan mana yang nyata, namun dalam beberapa kasus kisah-kisah horor terkadang justru menimbulkan trauma dan ketakutan yang berlebihan pada mereka. Fakta bahwa tokoh-tokoh hantu atau antagonis dalam semua cerita-cerita horor Fantasteen tersebut juga remaja atau bahkan anak-anak, maka hal ini makin didukung oleh pendapat Erikkson (2013:12) bahwa dalam kisah-kisah bertema misteri, penampilan luar anak-anak atau kaum muda yang polos dan terkesan baik- 
baik sesungguhnya lebih ampuh menyembunyikan kekejaman dan kejahatan, yang justru akan memancing reaksi heboh dari audiens.

Kembali dikaitkan dengan konsep dasar pemikiran Bourdieu, disimpulkan bahwa penerbit DAR! Mizan sengaja membuat lini Fantasteen dan lantas mencanangkan seri Ghost Dormitory untuk lebih mengukuhkan posisi mereka dalam praktik komersial sastra lewat penetapan genre yang spesifik, yang dibuat oleh remaja dan ditujukan untuk kaum muda pula. Melihat kemungkinan keberlangsungan genre horor yang akan terus direproduksi oleh industri budaya di Indonesia lewat berbagai media, baik film, karya sastra atau yang lainnya, maka DAR! Mizan dianggap telah berhasil memberikan pengaruh yang cukup signifikan pada wajah arena sastra Indonesia, terutama bagi kaum anak-anak dan remaja, di mana tema horor menjadi andalan sekaligus standar utama bagi karya-karya yang dianggap menjual. Genre horor sendiri sangat dekat dengan mayoritas masyarakat Indonesia, sehingga tidak sulit bagi penerbit untuk memasarkan genre tersebut dalam karya-karya para penulis mereka dan meraih legitimasi yang kokoh melalui produksi kultural novel khusus anakanak dan remaja bergenre horor. Tambahan lagi, pengintegrasian genre horor yang spesifik dalam karya sastra anak dan remaja juga dirasa lebih menguntungkan secara material oleh karena selama ini aspek tersebut kurang mendapat perhatian dari para penulis dan penerbit karya-karya untuk orang dewasa, dengan tambahan pula bahwa DAR! Mizan serius mempertahankan citra sebagai penerbit buku anak-anak dan remaja yang edukatif dengan melarang para penulis mereka untuk menyertakan unsur romansa di dalam cerita. 


\section{SIMPULAN}

Seri Ghost Dormitory dari lini Fantasteen yang diterbitkan oleh DAR! Mizan masih termasuk dalam genre mayor fantasi oleh karena adanya fenomena-fenomena supernatural yang disuguhkan di dalamnya, namun ia juga termasuk dalam genre uncanny yang bersifat aneh dan gaib, sebagaimana yang dicetuskan Todorov karena menitikberatkan pada penuntutan penjelasan logis yang mengungkap kemisteriusan fenomenafenomena yang ada tersebut. Kemunculan seri tersebut juga dianggap sebagai salah satu strategi DAR! Mizan selaku agen praktik produksi kultural dalam memantapkan posisi mereka di dunia sastra Indonesia, secara spesifik pada dunia sastra anak dan remaja. Selain itu, penerbit DAR! Mizan dianggap berhasil memperoleh legitimasi sekaligus profit finansial yang besar dengan menjadi penyuplai kisah-kisah anak dan remaja yang tampak edukatif dan konsisten dibandingkan penerbitpenerbit lain.

\section{DAFTAR RUJUKAN}

Bourdieu, P. 1989. Social Space and Symbolic Power. Sociological Theory Vol. 7 No. 1, 14-25.

Bourdieu, P. 1993. The Field of Cultural Production: Essays on Art and Literature. Cambridge: Polity.

Daniels, L. 1977. Fear: A History of Horror in the Mass Media. New York: Paladin.

Elmania, M. 2015. Ghost Dormitory in Den Haag. Bandung: DAR! Mizan Anggota IKAPI. 
Erikkson, J. 2013. Evil and Innocence: Children in Ghost Stories by Elizabeth Gaskell, M.R. James, and Susan Hill. Literary Specialization, Linkoping University, Department of Culture and Communication, 144.

Gilmore, L. A. 2008. Scared but loving it: Children's enjoyment of fear as a diagnostic marker of anxiety? Australian Educational and Developmental Psychologist, 1-15.

Haryatmoko. 2016. Membongkar Rezim Kepastian: Pemikiran Kritis PostStrukturalis. Yogyakarta: PT Kanisius.

Karnanta, K. Y. 2013. Paradigma Teori Arena Produksi Kultural Sastra: Kajian Terhadap Pemikiran Pierre Bourdieu. Jurnal Poetika Vol. 1 No. 1, 3-15.

Moktikanana, M. 2016. Ghost Dormitory in Tanzania. Bandung: Penerbit DAR! Mizan Anggota IKAPI.

Pustaka, P. M. 2016, Mei 03. DAR! MIZAN. Retrieved from Mizan: http://www.mizan.com/dar/

Santana, C. M. 2006. The World of the Fantastic as a Literary Genre: The Trace of a Quest in Angela Carter's The Bloody Chamber. Universidad de Las Palmas de Gran Canaria, 185-194. 